\title{
On the exchange of sensible and latent heat between the atmosphere and melting snow
}

\author{
Authors: Paul C. Stoy, Erich Peitzsch, David Wood, Daniel \\ Rottinghaus, Georg Wohlfahrt, Michael Goulden, and Helen \\ Ward
}

NOTICE: this is the author's version of a work that was accepted for publication in Agricultural and Forest Meteorology. Changes resulting from the publishing process, such as peer review, editing, corrections, structural formatting, and other quality control mechanisms may not be reflected in this document. Changes may have been made to this work since it was submitted for publication. A definitive version was subsequently published in Agricultural and Forest Meteorology, Volume 252, April 2018, DOI\#10.1016/j.agrformet.2018.01.028

Stoy, Paul C. , Erich Peitzsch, David Wood, Daniel Rottinghaus, Georg Wohlfahrt, Michael Goulden, and Helen Ward. "On the exchange of sensible and latent heat between the atmosphere and melting snow." Agricultural and Forest Meteorology 252 (April 2018): 167-174. DOI:10.1016/j.agrformet.2018.01.028. 


\title{
On the exchange of sensible and latent heat between the atmosphere and melting snow
}

\author{
Paul C. Stoy ${ }^{\mathrm{a}, *}$, Erich Peitzsch ${ }^{\mathrm{b}, \mathrm{c}}$, David Wood $^{\mathrm{a}, \mathrm{c}}$, Daniel Rottinghaus ${ }^{\mathrm{a}}$, Georg Wohlfahrt ${ }^{\mathrm{d}}$, \\ Michael Goulden ${ }^{\mathrm{e}}$, Helen Ward ${ }^{\mathrm{f}, \mathrm{g}}$ \\ ${ }^{a}$ Department of Land Resources and Environmental Sciences, Montana State University, Bozeman, MT, USA \\ ${ }^{\mathrm{b}}$ Department of Earth Sciences, Montana State University, Bozeman, MT, 59717 USA \\ ${ }^{c}$ U.S. Geological Survey Northern Rocky Mountain Science Center, Bozeman, MT, 59717, USA \\ d Institute of Ecology, University of Innsbruck, Sternwartestrasse 15, 6020 Innsbruck, Austria \\ e Department of Earth System Science, University of California, Irvine, Irvine, CA, 92697, USA \\ ${ }^{\mathrm{f}}$ Department of Meteorology, University of Reading, Reading, RG6 6BB, United Kingdom \\ ${ }^{\mathrm{g}}$ Institute of Atmospheric and Cryospheric Sciences, University of Innsbruck, 6020 Innsbruck, Austria
}

\begin{abstract}
A B S T R A C T
The snow energy balance is difficult to measure during the snowmelt period, yet critical for predictions of water yield in regions characterized by snow cover. Robust simplifications of the snowmelt energy balance can aid our understanding of water resources in a changing climate. Research to date has demonstrated that the net turbulent flux $\left(F_{T}\right)$ between a melting snowpack and the atmosphere is negligible if the sum of atmospheric vapor pressure $\left(e_{a}\right)$ and temperature $\left(T_{a}\right)$ equals a constant, but it is unclear how frequently this situation holds across different sites. Here, we quantified the contribution of $F_{T}$ to the snowpack energy balance during 59 snowmelt periods across 11 sites in the FLUXNET2015 database with a detailed analysis of snowmelt in subarctic tundra near Abisko, Sweden. At the Abisko site we investigated the frequency of occurrences during which sensible heat flux $(H)$ and latent heat flux $(\lambda E)$ are of (approximately) equal but opposite sign, and if the sum of these terms, $F_{T}$, is therefore negligible during the snowmelt period. $H$ approximately equaled $-\lambda E$ for less than $50 \%$ of the melt period and $F_{T}$ was infrequently a trivial term in the snowmelt energy balance at Abisko. The reason is that the relationship between observed $e_{a}$ and $T_{a}$ is roughly orthogonal to the "line of equality" at which $H$ equals $-\lambda E$ as warmer $T_{a}$ during the melt period usually resulted in greater $e_{a}$. This relationship holds both within melt periods at individual sites and across different sites in the FLUXNET2015 database, where $F_{T}$ comprised less than $20 \%$ of the energy available to melt snow, $Q_{m}$, in $44 \%$ of the snowmelt periods studied here. $F_{T} / Q_{m}$ was significantly related to the mean $e_{a}$ during the melt period, but not mean $T_{a}$, and $F_{T}$ tended to be near $0 \mathrm{~W} \mathrm{~m}^{-2}$ when $e_{a}$ averaged $c a .0 .5 \mathrm{kPa} . F_{T}$ may become an increasingly important term in the snowmelt energy balance across many global regions as warmer temperatures are projected to cause snow to melt more slowly and earlier in the year under conditions of lower net radiation $\left(R_{n}\right)$. Eddy covariance research networks such as Ameriflux must improve their ability to observe cold-season processes to enhance our understanding of water resources and surface-atmosphere exchange in a changing climate.
\end{abstract}

\section{Introduction}

Quantifying the snowpack energy balance is critical for water regulation and runoff prediction (Dettinger et al., 2015; Kay and Crooks, 2014; Marks et al., 2008; Troin et al., 2016), avalanche forecasting (Slaughter et al., 2009; Wever et al., 2016), and predicting changes to future snowpack persistence (Abatzoglou et al., 2014; Pederson et al., 2011). Interannual variability in weather and climate change impact the timing and magnitude of snowmelt (Cline, 1997; Grundstein and
Leathers, 1999; Hayashi et al., 2005; Pederson et al., 2013), and snowmelt is projected to occur earlier and more slowly in a warming climate under conditions of lower net radiation earlier in the season (Musselman et al., 2017). To understand how snowmelt responds to climate variability, we must understand mass and energy fluxes to and from the snowpack, including key relationships that can simplify models without impacting their skill.

Using the convention that energy flux into the snowpack is positive, the energy available to melt snow, $Q_{m}$, is a function of the net radiation 
$\left(R_{n}\right.$, i.e. incident minus outgoing shortwave and longwave radiation), sensible heat flux $(H)$, latent heat flux $(\lambda E)$, ground heat flux $(G)$, and any energy flux due to precipitation ( $P$, Marks and Dozier, 1992; Burns et al. 2014):

$Q_{m}+Q_{c c}=R_{n}+H+\lambda E+G+P=R_{n}+F_{T}+G+P$.

$Q_{c c}$, the energy required to bring snow temperature to melting temperature (often called the cold content), is assumed here to be $0 \mathrm{~W}$ $\mathrm{m}^{-2}$ when the snowpack is melting. The net turbulent flux, $F_{T}$, is the sum of $H$ and $\lambda E$, the latter being of particular interest to snow science as it represents sublimation and evaporation from and condensation to the snowpack, and is thus connected to the snow mass balance. $H$ and $\lambda E$ tend to be minor but nontrivial contributions to $Q_{m}$ (Boon, 2009; Cline, 1997; Harding and Pomeroy, 1996; Fitzpatrick et al. 2017; Marks and Winstral, 2001) and are arguably more difficult to measure via, for example, eddy covariance compared to the radiometers and heat flux plates used to measure $R_{n}$ and $G$ (Arck and Scherer, 2002). Understanding situations in which the contribution of $F_{T}$ to $Q_{m}$ is negligible would dramatically simplify our ability to measure and model $Q_{m}$.

In a comparison of studies at alpine sites over portions of the melt period, Cline (1997) found that the contribution of $R_{n}$ to $Q_{m}$ ranged from 0 to $100 \%$, illustrating that $F_{T}$ can be both a negligible and dominant source of energy for snowmelt. $F_{T}$ can dominate $Q_{m}$ in arid environments, especially in the early season before $R_{n}$ reaches higher values (Beaty, 1975; Hawkins and Ellis, 2007). The contribution of $F_{T}$ to $Q_{m}$ can vary due to weather patterns (Cline, 1997; Grundstein and Leathers, 1999; Hayashi et al., 2005), wind speed (Mott et al., 2011; Pohl et al., 2006), and vegetation (Endrizzi and Marsh, 2010; Mahrt and Vickers, 2005), which makes model simplification difficult. However, the time scales of these comparisons range from the entire snow covered period to less than a week, and it is unclear how frequently, and under which conditions, $F_{T}$ contributes negligibly to $Q_{m}$ when snow is melting.

Welch et al. (2016) used eddy covariance measurements in a montane continental snowpack in Montana, USA, and found that $H$ was only about $10 \%$ less than the magnitude of $-\lambda E$, such that $F_{T}$ $\left(-3 \mathrm{MJ} \mathrm{m}^{-2}\right)$ provided a negligible contribution to $Q_{m}\left(97 \mathrm{MJ} \mathrm{m}^{-2}\right)$ when integrated over the entire melt period. They described a linear relationship between near-surface air temperature $\left(T_{a}\right)$ and atmospheric vapor pressure $\left(e_{a}\right)$ for conditions under which $H=-\lambda E$ (Fig. 1, i.e. $F_{T}$ $=0 \mathrm{~W} \mathrm{~m}^{-2}$ and the Bowen ratio $\beta=H / \lambda E=-1$ ) that results when snow surface temperature $\left(T_{s s}\right)$ is at $0{ }^{\circ} \mathrm{C}$ when snow is melting. It was noted that average $T_{a}$ and $e_{a}$ during the melt period fell near the line at

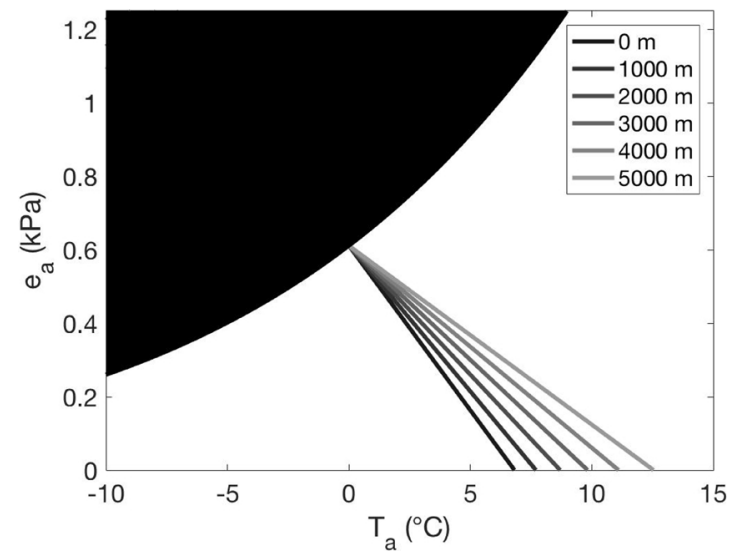

Fig. 1. The atmospheric vapor pressure $\left(e_{a}\right)$ and temperature $\left(T_{a}\right)$ at which energy flux into snow from sensible heat $(H)$ and losses from latent heat $(\lambda E)$ during snowmelt are equal (i.e. $H=-\lambda E$ ) following Welch et al. (2016) for different elevations above sea level and therefore mean psychrometric constants $(\gamma)$, which are a function of atmospheric pressure with minor temperature dependency as discussed in Loescher et al. (2009). The black shaded area denotes the region for which $e_{a}$ exceeds saturation over ice following Goff and Gratsch (1945). which $H=-\lambda E$, hereafter the "line of equality", and derived below in Methods. It is unclear if other melting snowpacks experience similar average climate conditions that make $F_{T}$ negligible during the melt period and therefore when $R_{n}$ measurements alone provide an accurate approximation of $Q_{m}$ (Eq. (1), noting that the magnitude of $G$ is often trivial compared to other terms in Eq. (1) during snowmelt.

Here, we quantify the contribution of $F_{T}$ to $Q_{m}$ during two snowmelt periods at a subarctic tundra research site near Abisko, Sweden and 59 snowmelt periods across 11 eddy covariance study sites in the FLUXNET2015 database (Pastorello et al., 2017) to quantify the range of meteorological conditions encountered during the melt period in different snowpacks. We examined two questions. First, are the micrometeorological conditions during the snowmelt period observed in Welch et al. (2016) common for various sites with different physical characteristics? To address this question, we examined eddy covariance and radiometric measurements of energy exchange between the snowpack and the atmosphere from sites in different climate zones. Second, how frequently is $F_{T}$ approximately equal to $0 \mathrm{~W} \mathrm{~m}^{-2}$, and what is the relative contribution of $F_{T}$ to $Q_{m}$ during the snowmelt period across sites? To address this question we study the distribution of micrometeorological conditions during different melt events. The goal of this analysis is to gain a better understanding of conditions in which the snowmelt energy balance can be accurately approximated using radiometric observations to simplify measurements and models. We focus our discussion on the steps necessary to improve observations of cold season processes within surface-atmosphere flux networks like Ameriflux, and to improve observations of climate and surface-atmosphere flux at snowmelt measurement networks like SNOTEL (snowpack telemetry, Serreze et al., 1999).

\section{Methods}

\subsection{Snow energy balance and turbulent flux during snowmelt}

Welch et al. (2016) present a relationship in which the input of $H$ to the snowpack is equal to $-\lambda E$ (i.e. $F_{T}=0 \mathrm{~W} \mathrm{~m}^{-2}$ ) when snow is melting. Briefly, $H$ can be written following e.g. Kaimal and Finnigan (1994):

$H=\frac{\rho C_{p}}{r_{H}}\left(T_{a}-T_{s s}\right)$

where $\rho$ is the molar density of air measured in $\mathrm{mol} \mathrm{m}^{-3}, C_{p}$ is the specific heat of dry air $\left(\mathrm{J} \mathrm{mol}^{-1} \mathrm{~K}^{-1}\right)$, and $r_{H}$ is the resistance to heat flux $\left(\mathrm{s} \mathrm{m}^{-1}\right) . H$ is positive when $T_{a}$ exceeds $T_{s s}$ noting the convention here that energy flux from the atmosphere to the snowpack is positive; positive $H$ denotes heat transport from the surface to the atmosphere in conventional flux studies. Welch et al. (2016) assumed that $T_{s s}$ is $0{ }^{\circ} \mathrm{C}$ (273.15 K) when snow was melting. Thus,

$H=\frac{\rho C_{p} T_{a}}{r_{H}}$

We note that $T_{s s}$ in Eq. (2) is the aerodynamic surface temperature, which is the temperature that influences turbulent flow. The aerodynamic surface temperature is similar to radiative surface temperature if melting snow can be considered a smooth surface for the case of eddy covariance research sites, and is thus related to the outgoing longwave radiation $\left(L W_{\text {out }}\right)$ following the Stefan-Boltzmann equation:

$L W_{\text {out }}=A \varepsilon \sigma T_{s r}^{4}$

where $A$ is the view factor (assumed to be 1 for a melting snowpack on a flat surface), $\sigma$ is the Stefan-Boltzmann constant, $\varepsilon$ is the emissivity of snow (which changes as a function of snow characteristics, e.g. Hori et al., 2006), and $T_{s r}$ is the radiometric snow surface temperature in degrees Kelvin, $273.15 \mathrm{~K}$ if snow is melting. Aerodynamic and radiometric surface temperatures are otherwise different terms.

Like $H, \lambda E$ can be written: 
$\lambda E=\frac{\rho C_{p}}{\gamma r_{v}}\left(e_{a}-e\left[T_{s s}\right]\right)$

where $r_{v}$ is the resistance to latent heat flux $\left(\mathrm{s} \mathrm{m}^{-1}\right), e\left[T_{s s}\right]$ is the vapor pressure at the snow surface, and $\gamma$ is the psychrometric constant. $\gamma$ is not a true constant, and varies a function of atmospheric pressure $\left(P_{a}\right)$ following e.g. Campbell and Norman (1998):

$\gamma=C_{p} P_{a} /(0.622 \lambda)$

where 0.622 is the ratio of the molecular mass of water vapor to dry air. We note that $\gamma$ exhibits minor temperature dependency assumed to be trivial here (Loescher et al., 2009).

$\lambda E$ tends to be negative during the melt period (i.e. sublimation and evaporation to the atmosphere dominate condensation to the snowpack) because the melting and sublimating snow surface is saturated but the overlying air usually is not (Marks and Dozier, 1992; Reba et al., 2009). Assuming again that $T_{s s}$ is $0{ }^{\circ} \mathrm{C}$ during the melt period, $e_{a}$ at saturation is $0.61173 \mathrm{kPa}$. Further, $r_{v}$ is similar to $r_{H}$ in the absence of vegetation (Campbell and Norman, 1998) such that

$\lambda E \approx \frac{\rho C_{p}}{\gamma r_{H}}\left(e_{a}-0.61173\right)$.

When $H$ and $\lambda E$ are assumed to be equal but opposite, the expression can be simplified to yield a linear relationship between $e_{a}$ and $T_{a}$ that varies as a function of $\gamma$ (Welch et al., 2016)

$\gamma T_{a}+e_{a}=0.61173$

Mean $T_{a}$ and $e_{a}$ during the melt period can provide insight into the dynamics of $F_{T}$ because Eq. (8) is linear, and we study both mean $T_{a}$ and $e_{a}$ during the entire melt period and their variability at the half-hourly time steps commonly used in eddy covariance studies.

\subsection{Study sites: selection criteria}

Difficulties arise when measuring the energy balance of melting snow below forest canopies where the well-developed turbulence favored for eddy covariance measurements is rarely encountered (Misson et al., 2007; Staebler and Fitzjarrald, 2004). In addition, canopies can lead to a decoupling of sub-canopy and above-canopy fluxes (Burns et al., 2014; Jocher et al., 2017; Thomas et al., 2013), complicating the interpretation of results from flux towers, and requiring additional instrumentation to understand snow versus canopy impacts on surfaceatmosphere exchange (although see: Molotch et al., 2007; Burns et al., 2014; Welch et al., 2016). We focused our study on sites in predominately open areas or open canopies in which the exchange of energy between the snow itself and the atmosphere can be measured more readily

\subsubsection{Study sites: Abisko, Sweden}

The Abisko, Sweden subarctic tundra research site is at an elevation of $752 \mathrm{~m}$ above sea level at $68.299 \mathrm{~N}, 18.847 \mathrm{E}$ (Fox et al. 2008; Stoy et al., 2012, 2013). $H$ was measured using a Gill R3 sonic anemometer and $\lambda E$ was measured using the eddy covariance approach by coupling the anemometer with a LI-COR 7500 infrared gas analyzer (Li-Cor, Lincoln, Nebraska, U.S.A), both at $3 \mathrm{~m}$ above the ground surface. Halfhourly fluxes were calculated using FluxView (Centre for Ecology and Hydrology, Wallingford, U.K.) as described in more detail in Stoy et al. (2013). $H$ and $\lambda E$ observations that did not meet a turbulence intensity threshold of a friction velocity $\left(\mathrm{u}_{*}\right)$ of greater than $0.08 \mathrm{~m} \mathrm{~s}^{-1}$ determined using $\mathrm{CO}_{2}$ flux observations were excluded from the analysis. $T_{a}$ and relative humidity $(R H)$ were measured using a HMP45 sensor (Vaisala, Helsinki, Finland), at a height of $2 \mathrm{~m} . e_{a}$ was calculated from $T_{a}$ and $R H$ measurements as described in Section 2.4.

Snow presence was estimated using observations of reflected shortwave radiation measured at $2 \mathrm{~m}$ using a downward-facing CM11 secondary standard pyranometer (Kipp and Zonen, Delft, The
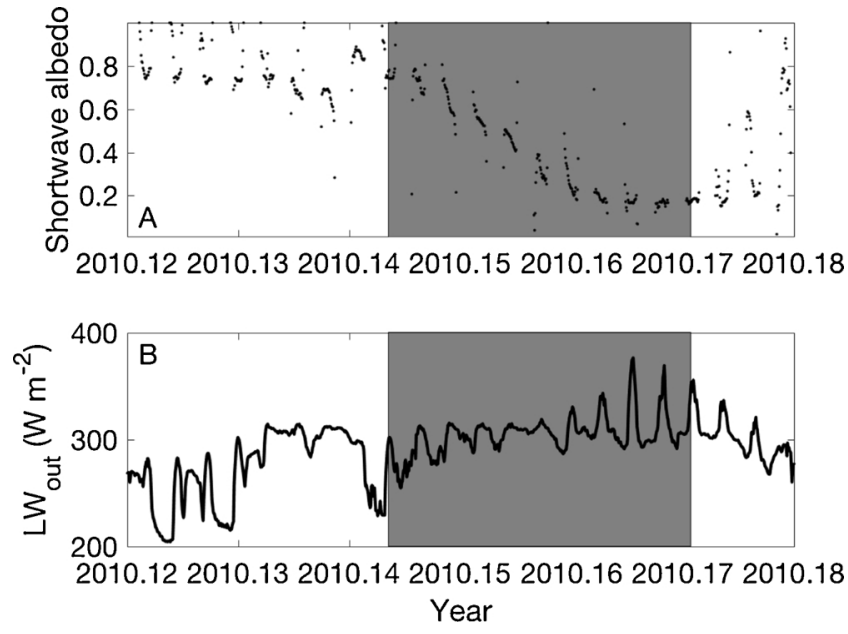

Fig. 2. An example snowmelt period (gray shading) from the Neustift, Austria (AT-Neu) eddy covariance research site as determined by the shortwave albedo (subplot A) and outgoing longwave radiation ( $L W_{\text {out }}$, subplot $\mathrm{B}$ ). The melt period is considered to begin when $L W_{\text {out }}$ reaches a local maximum after when shortwave albedo simultaneously begins to decline, and ends before $L W_{\text {out }}$ follows a clear diurnal pattern and shortwave albedo values are characteristic of a snow-free land surface. Only periods in which calculated $Q_{m}$ are greater than $0 \mathrm{~W} \mathrm{~m}^{-2}$ within this period is considered the 'melt period' for the purposes of this analysis, and the implications of these assumptions regarding melt period definition are discussed in the Discussion section.

Netherlands). The beginning of the snowmelt period was defined as the periods of consistent declines in observed snow depth (measured using a Cambpell Scientific SR50 sonic distance sensor) in 2009. Snow depth measurements were not available in 2008 , and the beginning of the snowmelt period in 2008 is defined as the day at which measurements began after the tower power system was repaired on April 10, 2008 following damage the previous winter. $L W_{\text {out }}$ observations were unfortunately not available at the Abisko site, and we instead define periods of melting snow within the defined snowmelt periods as those for which calculated $Q_{m}$ was greater than $0 \mathrm{Wm}^{-2}$. We discuss the consequences of these assumptions in the Discussion section.

\subsubsection{Study sites: FLUXNET2015}

To avoid complications posed by vegetation measuring energy exchange between a melting snowpack and the atmosphere, we study sites characterized as grasslands, croplands, or open shrublands in the FLUXNET2015 database and attempt to avoid situations of emerging vegetation as described in Fig. 2. The FLUXNET2015 sites studied here included energy balance measurements (Eq. (1) including eddy covariance measurements of $H$ and $\lambda E$ and radiometric observations of $T_{s s}$ (via outgoing longwave radiation) as well as standard $T_{a}$ and $R H$ measurements in areas with distinct snow accumulation and ablation seasons, differing climate types (Kottek et al., 2006), and elevations (Table 1). Measurement details are noted in the references associated with each site and listed in Table 1 . Snowmelt periods were defined by quantifying periods with declining shortwave albedo and near-constant $L W_{\text {out }}$ as demonstrated in Fig. 2. The explicit assumption with this approach is that albedo decreases during snowmelt, be it due to the appearance of impurities and/or changes in grain size (e.g. Warren, 1984), and that near-constant $L W_{\text {out }}$ reflects a snowpack that is melting with minimal changes in $Q_{c c}$. Only melt periods that occurred over the course of multiple days and without energy input from precipitation events are examined here. We likewise only study periods with measured (not gapfilled) turbulent fluxes during periods when $Q_{m}>0 \mathrm{Wm}^{-2}$ as at the Abisko study site. $G$ has been found to be negligible in most locations with snow cover (Boike, 2003; Cline, 1997; Welch et al., 2016) and was assumed to be zero. The consequences of these assumptions are discussed in the Discussion section. We then calculated the relative contributions of $F_{\mathrm{T}}$ and $R_{n}$ to $Q_{m}$ using Eq. (1). 
Table 1

The latitude, longitude, elevation (above sea level) and International GeosphereBiosphere Programme (IGBP) vegetation classification for FLUXNET2015 research sites with albedo and outgoing longwave radiation measurements to estimate melt periods following Fig. 2. CRO: crop; GRA: grass; OSH: open shrub; WET: wetland. *Three nearby agricultural fields are measured near Mead, Nebraska. We choose the site US-Ne1 as representative for all three.

\begin{tabular}{|c|c|c|c|c|c|}
\hline Site & Lat & Long & $\begin{array}{l}\text { Elevation (m } \\
\text { asl) }\end{array}$ & IGBP & Reference \\
\hline AT-Neu & 47.1167 & 11.3175 & 970 & GRA & Wohlfahrt et al. (2008) \\
\hline CH-Fru & 47.1158 & 8.5378 & 982 & GRA & $\begin{array}{l}\text { Eugster and Zeeman } \\
(2006)\end{array}$ \\
\hline CZ-wet & 49.0247 & 14.7704 & 426 & WET & \\
\hline DE-Geb & 51.1001 & 10.9143 & 162 & CRO & Anthoni et al. (2004) \\
\hline DE-Gri & 50.9495 & 13.5125 & 385 & GRA & Owen et al. (2007) \\
\hline DE-Kli & 50.8929 & 13.5225 & 478 & CRO & Owen et al. (2007) \\
\hline DE-SfN & 47.8064 & 11.3275 & 590 & WET & $\begin{array}{l}\text { Hommeltenberg et al. } \\
\text { (2014) }\end{array}$ \\
\hline FI-Lom & 67.9972 & 24.2092 & 274 & WET & Aurela et al. (2009) \\
\hline IT-MBo & 46.1047 & 11.0458 & 1550 & GRA & Marcolla et al. (2011) \\
\hline IT-Tor & 45.8444 & 7.5781 & 2160 & GRA & $\begin{array}{l}\text { Migliavacca et al. } \\
\text { (2011) }\end{array}$ \\
\hline US-Ne1* & 41.1651 & -96.4766 & 361 & CRO & Verma et al. (2005) \\
\hline
\end{tabular}

We note that snowmelt periods estimated within the footprint of the radiometer and those measured by the eddy covariance flux footprint are likely to be different, and discuss strategies for observing cold season processes in tower measurement networks in the Discussion section.

\subsection{Calculation of variables}

For each site we used $R H$ and $T_{a}$ recorded during the snowmelt period to quantify $e_{a}$ and calculated the saturated vapor pressure $\mathrm{e}_{\mathrm{s}}\left(T_{a}\right)$ over ice for a given temperature using the Goff and Gratch (1945) equation:

$$
\begin{aligned}
\log _{10} e_{S}\left(T_{a}\right)= & -9.09718\left(T_{0} / T_{a}-1\right)-3.56654 \log _{10}\left(T_{0} / T_{a}\right)+0.876793\left(1-T / T_{0}\right) \\
& +\log _{10} e_{i 0}^{*}
\end{aligned}
$$

where $T_{0}$ is the triple point temperature of water $(273.16 \mathrm{~K})$ and $e_{\mathrm{i0}}^{*}$ is the saturated vapor pressure of water at $0{ }^{\circ} \mathrm{C}$ in $\mathrm{hPa}(6.1173 \mathrm{hPa}) . e_{a}$ was then calculated by multiplying $R H$ (as a fraction) by $e_{s}$.

As our sites varied in elevation, we calculated $\gamma$ using

$\gamma=0.665 \times 10^{-3} P_{a}$

Average $P_{a}$ as a function of elevation above sea level ( $h$, see Table 1$)$ was calculated using

$P_{a}=101.3\left(\frac{293-0.0065 h}{293}\right)^{5.26}$

following e.g.Zhu et al. (2012). $\beta$ was calculated as $H / \lambda E$ excluding periods for which the absolute value of $\lambda E$ was less than $1 \mathrm{~W} \mathrm{~m}^{-2}$.

\section{Results}

\subsection{Snowmelt at Abisko}

The snowmelt events during both 2008 and 2009 at Abisko began during the second week of April and ended on May 3, 2008 and April 24, 2009, respectively (Table 2). $T_{a}, e_{a}$, and $R_{n}$ were, on average, greater during the 2008 melt period (Table 2), which extended until May when $R_{n}$ was greater. Mean $T_{a}$ and $e_{a}$ fell to the warmer side of the line of equality in 2008, conditions which theoretically favor greater $H$ over the magnitude of $\lambda E$ (Welch et al., 2016), and the cooler side in 2009. Observations, however, suggested that the magnitude of $\lambda E$ was greater than $H$ in 2008 and less than $H$ in 2009 (Table 2). The magnitude of mean $F_{T}$ was greater than $10 \mathrm{~W} \mathrm{~m}^{-2}$ during both melt periods, and mean $Q_{m}$ was on the order of $20 \mathrm{~W} \mathrm{~m}^{-2}$ such that $F_{T}$ could not be excluded from the energy balance Eq. (1) for a robust estimate of $Q_{m}$.

The distribution of $H$ during the melt period of 2008 had a heavy tail toward negative values (indicating surface heating) (Fig. 4A), which resulted in a similar distribution of $F_{T}$ (Fig. 4B), noting that peak $F_{T}$ occurred near $0 \mathrm{~W} \mathrm{~m}^{-2}$ in both 2008 and 2009. Latent heat loss from the snowpack (negative values in Fig. 4C) dominated positive values (indicating condensation) during both melt periods. The distribution of $\beta$ had a minor peak near -1 (the value at which $H=-\lambda E$ ) during 2008 and a relatively high density of observations of $\beta$ near -1 in 2009. The analysis of mean values during the melt period and individual halfhourly points both indicate that conditions frequently occur in which $F_{T}$ is negligible, but also that the full melt period cannot be assumed to have negligible $F_{T}$.

\subsection{Snowmelt at FLUXNET2015 research sites}

Snowmelt periods at the FLUXNET2015 research sites (Table 1) were determined by examining $L W_{\text {out }}$ and albedo time series as demonstrated in Fig. 2. Mean $T_{a}$ across all sites during the defined melt period was $2.6^{\circ} \mathrm{C}$ and mean $e_{a}$ was $0.56 \mathrm{kPa}$ (Fig. 5). Mean $T_{a}$ was significantly related to $e_{a}(p=0.001)$ and explained $24 \%$ of the variability of $e_{a}$ such that the distribution of observed $T_{a}$ and $e_{a}$ was approximately orthogonal to the line of equality (Fig. 5).

$F_{T}$ comprised between - $96 \%$ (i.e. of opposite sign than $R_{n}$ ) and $108 \%$ of $Q_{m}$ across the 60 FLUXNET2015 melt periods studied (Fig. 6) and its absolute value was less than $15 \%$ of $Q_{m}$ on 22 instances, in other words during $37 \%$ of the melt periods studied. If uncertainty in eddy covariance measurements can be assumed to be on the order of $10-20 \%$ (e.g. Goulden et al., 1997), there are many examples in which $F_{T}$ need not be measured for a robust estimate of $Q_{m}$ given observational uncertainties, but these instances are in the minority of the snowmelt periods studied here. The ratio $F_{T} / Q_{m}$ was not related to variability in mean $T_{a}$ during the melt periods $(p=0.35)$, but was significantly related to mean $e_{a}$ ( $p=0.0002)$, which explained $21 \%$ of its variability. The point at which $F_{T} / Q_{m}$ crossed 0 (i.e. $F_{T}=0 \mathrm{~W} \mathrm{~m}^{-2}$ ) occurred when $e_{a}$ was approximately $0.5 \mathrm{kPa}$.

\section{Discussion}

The objectives of this study were to examine flux and micrometeorological measurements across multiple sites and snowmelt periods to identify periods when $F_{T}$ is a minor input to $Q_{m}$. The "line of equality" when this situation should theoretically occur was rarely encountered within or among melt periods. Instead, observed mean melt-period $e_{a}$ and $T_{a}$ observations were approximately orthogonal to the line of equality as warmer $T_{a}$ coincided with higher values of $e_{a}$ in snowmelt-dominated landscapes (Fig. 3 and 5). Because $e_{a}$ tends to be near its saturated value during snowmelt across the sites studied here, the point at which $F_{T}$ is predicted to be $0 \mathrm{~W} \mathrm{~m}^{-2}$ tended to occurs when $e_{a}$ was on the order of $0.5 \mathrm{kPa}$ and therefore $T_{a}$ on the order of $1-2{ }^{\circ} \mathrm{C}$ with minor sensitivities to $h$ and thereby $P_{a}$ (Fig. 1). Of course, influxes of warm and dry air (Cline, 1997; Grundstein and Leathers, 1999) such as Föhn winds and Chinooks (Desai et al., 2016; Hayashi et al., 2005; MacDonald et al., 2018; Zeeman et al., 2017) or other synoptic-scale patterns (Grundstein and Leathers, 1999) can result in situations where $e_{a}$ is not near saturation and greatly increases the energy available to melt snow by increasing both $T_{a}$ and the gradient in moisture to support $\lambda E$, thus deviating from the general trend that $e_{a}$ is related to $T_{a}$ during melt. Observing energy exchange between melting snowpacks and the atmosphere across multiple sites continues to be a challenge because measurement networks are not optimized to observe either cold season processes or surface-atmosphere exchange. We briefly discuss the Abisko and FLUXNET2015 results, and then outline the steps necessary to improve observations of cold season processes by research networks. 
Table 2

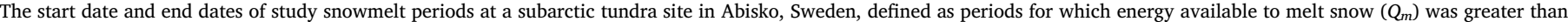

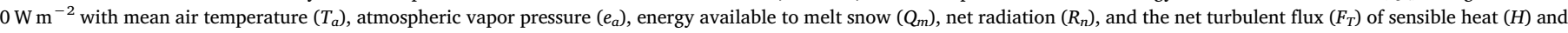
latent heat.

\begin{tabular}{|c|c|c|c|c|c|c|c|c|c|}
\hline Year & Start date & End date & Mean $T_{a}\left({ }^{\circ} \mathrm{C}\right)$ & Mean $e_{a}(\mathrm{kPa})$ & Mean $Q_{m}\left(\mathrm{~W} \mathrm{~m}{ }^{-2}\right)$ & Mean $R_{n}\left(\mathrm{~W} \mathrm{~m}^{-2}\right)$ & Mean $F_{T}\left(\mathrm{~W} \mathrm{~m}^{-2}\right)$ & Mean $H\left(\mathrm{~W} \mathrm{~m}^{-2}\right)$ & Mean $\lambda E\left(\mathrm{~W} \mathrm{~m}^{-2}\right)$ \\
\hline 2008 & April 11 & May 3 & 3.0 & 0.57 & 19 & 35 & -16 & 7 & -22 \\
\hline 2009 & April 10 & April 24 & 0.5 & 0.49 & 20 & 5 & 15 & 34 & -19 \\
\hline
\end{tabular}

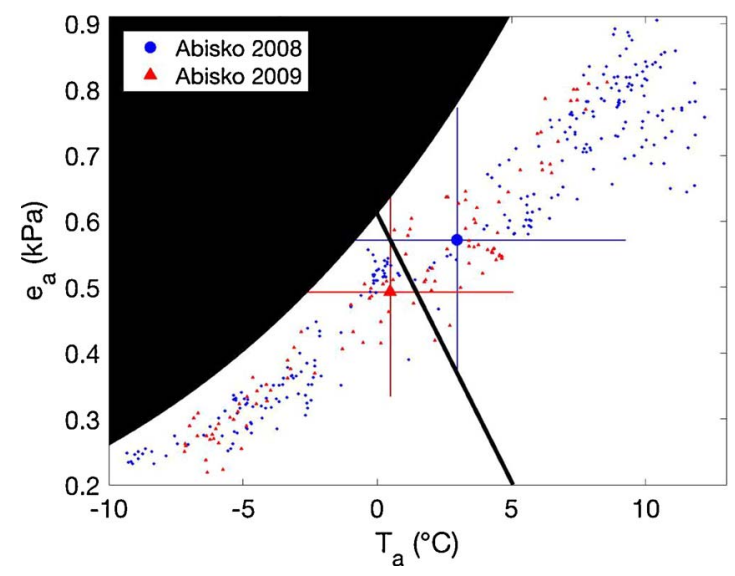

Fig. 3. Air temperature $\left(T_{a}\right)$ and atmospheric vapor pressure $\left(e_{a}\right)$ during the 2008 and 2009 snowmelt periods for a tundra site in Abisko, Sweden with half hourly measurements as small dots and mean values during snowmelt as large symbols with error bars (1 standard deviation). The solid black line represents the relationship between temperature and atmospheric vapor pressure where the net turbulent flux between snowpack and atmosphere is equal under conditions when the snow surface temperature is $0{ }^{\circ} \mathrm{C}$ at the elevation of the Abisko site $(752 \mathrm{~m}$ asl) and the black shaded area denotes the region for which $e_{a}$ exceeds saturation over ice following Goff and Gratsch (1945) (Eq. (9)).
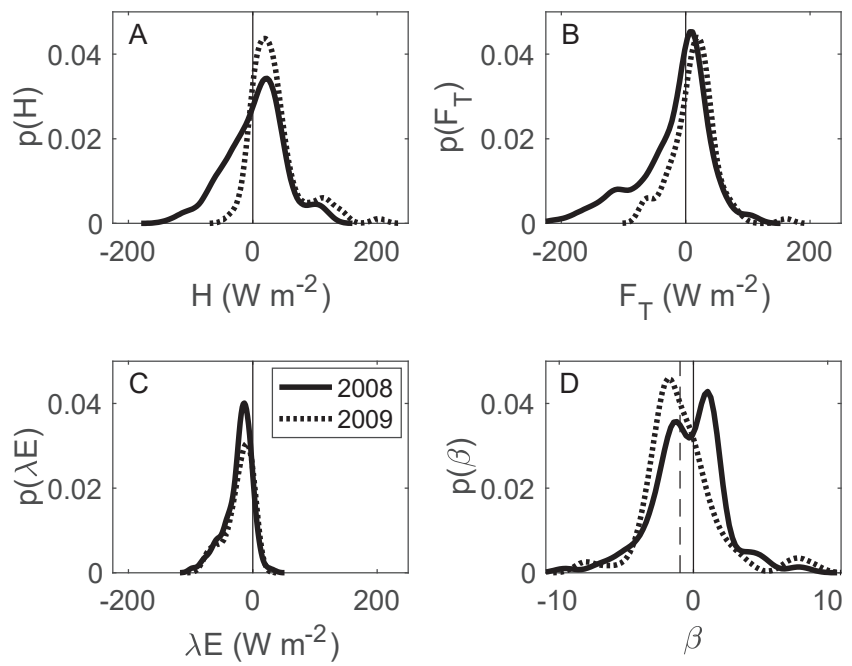

Fig. 4. The probability distributions of half hourly measurements of sensible heat flux ( $H$, panel A), the sum of turbulent fluxes $\left(F_{T}, \mathrm{~B}\right)$, the latent heat flux $(\lambda E, C)$, and the Bowen ratio $(\beta, D)$ during two snowmelt periods for a subarctic tundra site near Abisko, Sweden. Latent heat flux measurements with an absolute value less than $1 \mathrm{~W} \mathrm{~m}^{-2}$ were excluded from the calculation of $\beta$. The solid vertical lines represent the ordinate and the dashed vertical line in $\mathrm{D}$ represents a $\beta$ value of -1 .

\subsection{Abisko}

Measurements at Abisko highlighted the notion that $F_{T}$ can often be near $0 \mathrm{Wm}^{-2}$ when $Q_{m}$ is positive, but also that the simplification found by Welch et al. (2016) should not be transferred to different sites and melt periods as $F_{T}$ was a nontrivial term in $Q_{m}$ during both melt periods. Results also opposed the notion that the magnitude of $H$ should

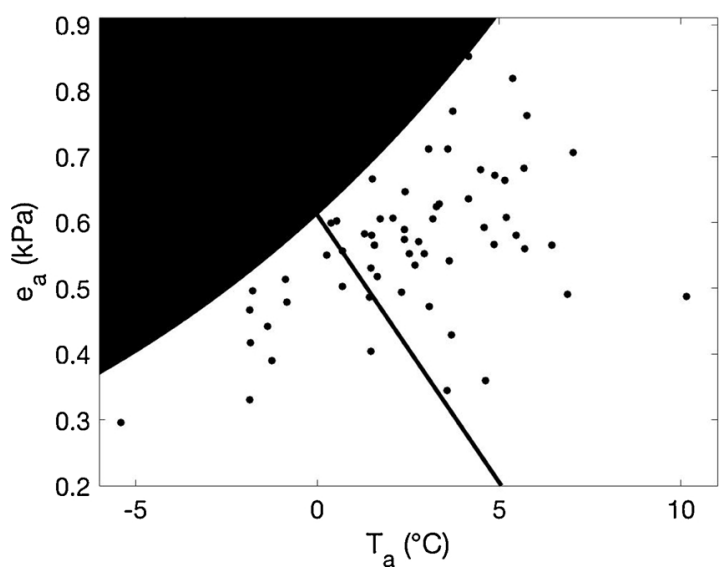

Fig. 5. Mean air temperature $\left(T_{a}\right)$ and atmospheric vapor pressure $\left(e_{a}\right)$ during snowmelt periods defined using outgoing longwave radiation and shortwave albedo observations following Fig. 3 for FLUXNET2015 sites with multi-day melt periods and short statured vegetation (Table 1). The solid black line represents the relationship between temperature and atmospheric vapor pressure where the net turbulent flux between snowpack and atmosphere is equal under conditions when the snow surface temperature is $0^{\circ} \mathrm{C}$ at an elevation of $752 \mathrm{~m}$ asl following Fig. 3 for reference.

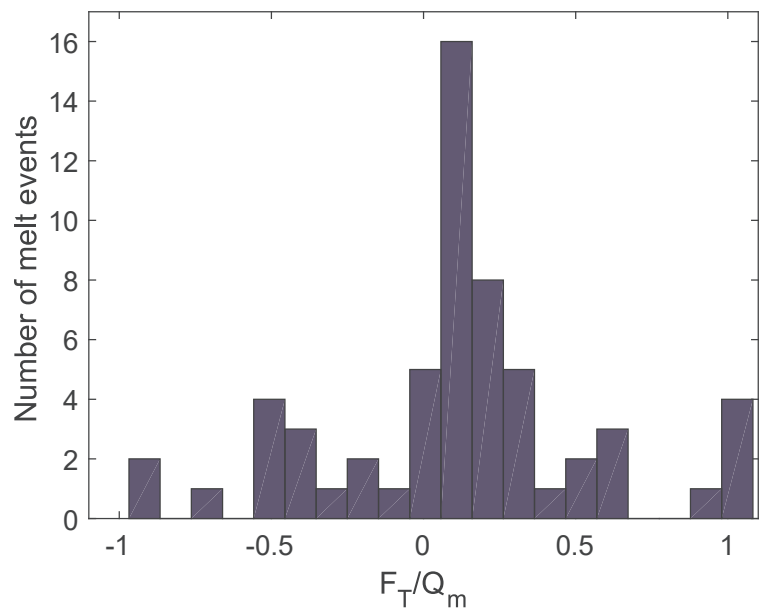

Fig. 6. The ratio between the mean turbulent flux $\left(F_{T}\right)$ and energy available to melt snow $\left(Q_{m}\right)$ during 59 melt periods across 11 FLUXNET2015 research sites described in Table 1.

exceed that of $\lambda E$ when average meteorological conditions fell "above" (warmer and moister than) the line of equality. This is likely because the assumption that a reflective surface (indicating snow) near the flux tower was not necessarily indicative of consistent snow cover across the turbulent flux footprint, which extends to the order of tens to hundreds of meters depending on atmospheric stability (Fox et al., 2008; Stoy et al., 2013).

It is likely in the case of the Abisko measurements that the footprint of the radiometer and sonic distance sensor used to define the beginning and end of the snowmelt period were poor approximations of continuous snow presence within the eddy covariance flux footprint. The Abisko site is characterized by patchy vegetation (Fletcher et al., 2012; Spadavecchia et al., 2008; Stoy et al., 2013; Stoy and Quaife 
2015). Vegetation patches, particularly of the moss Polytrichum piliferum, become exposed during the melt period and can even exhibit positive photosynthetic carbon uptake adjacent to and even under snow-covered patches (Street et al., 2012). Mosses tend to partition energy into $H$ as they lack vascular tissue to transport water (Liljedahl et al., 2011), and evaporation will be hastened by locally warm vegetation patches versus snow. Vegetation, even in situations where it is short-statured, can create spatial variability in snowmelt and influence turbulent flux when it is protruding from the snow (Endrizzi and Marsh, 2010; Mahrt and Vickers, 2005; Mott et al., 2013). It is unclear how positive $G$ from these melting vegetation and bare ground patches influence the surrounding energy balance, but our assumption that $G$ is approximately $0 \mathrm{Wm}^{-2}$ during the melt period is not likely valid, especially towards the end of melt periods when the snowpack is shallow and/or patchy. Complicated melt patterns within the flux footprint must be taken into account for an accurate understanding of melt processes, and we discuss how to do so in section 4.3.

\subsection{FLUXNET2015}

Mean $T_{a}$ and $e_{a}$ across melt periods for the FLUXNET2015 sites (Table 1 and Fig. 5) followed a positive relationship such that the point at which this relationship crossed the line of equality was on the order of $1-2{ }^{\circ} \mathrm{C}$ and $0.5 \mathrm{kPa}$. In other words, there were many instances in which mean $T_{a}$ and $e_{a}$ fell near the line of equality, but this was an exception rather than the rule. With uncertainty of eddy covariance observations in mind, $F_{T}$ comprised less than $20 \%$ of $Q_{m}$ some $43 \%$ of the time, but nearly $50 \%$ of the time when mean $e_{a}$ was between $0.5 \mathrm{kPa}$ and $0.7 \mathrm{kPa}$. In summary, conditions in which $F_{T}$ is negligible exist during parts of snowmelt periods or even cumulatively during the entire melt period (e.g. Welch et al., 2016), but at insufficient frequencies to justify not measuring or modeling turbulent fluxes for a full quantification of $Q_{m}$ (Fig. 1). The question then becomes: How do we to best make observations of cold season processes and integrate them into flux and snow networks?

\subsection{Improvements to micrometeorological networks to study the cold period}

Eddy covariance systems provide important information to quantify the terms that contribute to $Q_{m}$ at high (usually half-hourly) temporal resolution, but are rarely installed with cold season energy and water flux processes in mind e.g. (Molotch et al., 2007; Reba et al., 2009; Welch et al., 2016). Eddy covariance analyses can be greatly improved by simple additions of distance sensors, which for short (e.g. grass and crop) canopies also make for a nice automated measurement of canopy height during the active period (Jonas et al., 2008). It is also critical to measure the cold content of the snowpack using temperature sensors within the snowpack to measure the cold season energy balance, and doing so using thermocouples incurs minimal added expense. $Q_{c c}$ can be non-zero even within melt periods (Burns et al., 2014), but in the absence of snow temperature measurements it was necessary to assume that $Q_{c c}$ was negligible for the purposes of this analysis. Automated snow temperature sensors are an efficient way to test the validity of this assumption and better measure all terms in Eq. (1).

Without additional infrastructure, assumptions regarding snow presence and melting are necessary, and may or may not be robust. Our assumption that decreases in albedo correspond to the beginning of the melt period (e.g. Fig. 2) is an approximation that corresponds to known changes in snow albedo during melt due to changes in snow grain size and the melting of snow around impurities within the snowpack (e.g. Warren, 1984). Likewise, we assume that large changes in $Q_{c c}$ during refreezing can be assumed to be minimal if the snow surface stays near $0{ }^{\circ} \mathrm{C}$, which can be observed using $L W_{\text {out }}$. The notion that snowmelt occurs under relatively invariant $L W_{\text {out }}$ reflects the assumption that the $Q_{c c}$ is minimal during the melt period, but because refreezing occurs it must be quantified for a robust understanding of the melt period. Both assumptions used here (Fig. 2) would benefit from more detailed observations of temperature within the snowpack, including its cold content, as well as more detail about the cause of the albedo decrease, be it impurities (e.g. Conway et al., 1996) and/or increases in grain size during melt (Wiscombe and Warren, 1980).

As was likely the case for the Abisko observations, there may be important differences in what is being observed by tower-mounted radiometers and the eddy covariance system, which have different observational footprints. Phenological cameras - properly positioned are adept at observing spatial patterns of snow within flux footprints (Julitta et al. 2014) in order to understand when turbulent fluxes arise from a footprint that represents a matrix of melted and unmelted patches (Mott et al., 2013), especially given that flux towers themselves can (unintentionally) behave as miniature snow fences and result in minor accumulations that may influence radiometric measurements. Phenocam observations are increasingly common at eddy covariance research sites (Migliavacca et al., 2011; Richardson et al., 2009), and flux networks will continue to benefit from their inclusion, noting that phenocams (best pointed north) likewise are unlikely to have a similar observational footprint to the eddy covariance sensors.

A more complicated measurement recommendation to flux tower sites would be the addition of snow pillows as used in SNOTEL (SNOwpack TELemetry), which represent a larger cost and infrastructural investment, and may influence the non-snow covered flux footprint because they necessitate the removal of vegetation. The alternate solution is to manually measure snow mass and its changes over time, which likewise often represents a sizeable investment and may be impractical or dangerous in many situations, especially when the risk of avalanche activity is high and when travel over a landscape with melting snow becomes impractical. Larger infrastructural investments are also an option for studying snowmelt processes like condensation and sublimation. For example Hood et al., (1999) measured turbulent flux at multiple heights and moved sensors as a function of snowpack height, but these represent additional complexity for integration into flux networks. At a minimum, we recommend investments in depth sensors (which can also be used to measure vegetation height growth), noting that declines in snow depth may also correspond to wind-induced sublimation or settling. Phenological cameras, snow temperature sensors, and heated multi-component radiometers (to avoid snow covered radiometers, and including upwelling shortwave and longwave radiation measurements) improve our ability to observe cold-season processes, with the strong suggestion that incorporating snow pillows into existing eddy covariance sites will dramatically increase the ability of snow observing networks like SNOTEL to interact with surface-atmosphere exchange measurement networks such as Ameriflux.

An additional recommendation to couple process-based studies of snowmelt with observations is to add instrumentation to snow measurement networks like SNOTEL. SNOTEL sites are critical for water resource management (Serreze et al., 1999), long-term studies of hydrology (Bedford and Douglass, 2008), model validation (Coughlan and Running, 1997) and more, but rarely if ever include atmospheric humidity sensors or radiometers that are critical for understanding the mechanisms that drive $Q_{m}$. By adding instrumentation to eddy covariance networks to improve their ability to observe cold season processes, and to snow measurement networks to improve process-based studies, our ability to measure and model snow on a changing planet will be improved.

\section{Conclusion}

Observations demonstrate that the micrometeorological conditions that lead to periods when $H=-\lambda E$ during snowmelt occur infrequently because $e_{a}$ tends to increase with $T_{a}$ in landscapes characterized by melting snow. There are times when $H=-\lambda E$ during the snowmelt period as found by Welch et al (2016), but these conditions did not result in a situation where $F_{T}$ was a negligible contribution to $Q_{m}$ at a 
subarctic tundra ecosystem near Abisko, Sweden and in less than half of the snowmelt periods we examined in the FLUXNET 2015 database. In summary, $F_{T}$ needs to be measured and modeled for a robust understanding of snowmelt, but will frequently be a negligible term in the snowmelt energy balance.

Networks of flux towers can be used to further improve our understanding of snowmelt, especially if snow-specific measurements like snow temperature sensors or snow pillows are incorporated into flux measurement networks, or even if multi-purpose instrumentation like distance sensors or phenocams are included in flux measurement networks. Overall, our study illustrates the complexity of the energy balance during the snowmelt period at a variety of sites with low statured vegetation and the complexity of making these measurements, yet provides path forward for better understanding cold season processes in a changing climate.

\section{Acknowledgements}

This work used eddy covariance data acquired and shared by the FLUXNET community, including these networks: AmeriFlux, AfriFlux, AsiaFlux, CarboAfrica, CarboEuropeIP, CarboItaly, CarboMont, ChinaFlux, Fluxnet-Canada, GreenGrass, ICOS, KoFlux, LBA, NECC, OzFlux-TERN, TCOS-Siberia, and USCCC. The FLUXNET eddy covariance data processing and harmonization was carried out by the European Fluxes Database Cluster, AmeriFlux Management Project, and Fluxdata project of FLUXNET, with the support of CDIAC and ICOS Ecosystem Thematic Center, and the OzFlux, ChinaFlux and AsiaFlux offices. PCS acknowledges support from the U.S. National Science Foundation (DEB 1552976, OIA 1632810) and the USDA National Institute of Food and Agriculture Hatch project 228396. We thank Jon Evans and Colin Lloyd for work on Abisko eddy covariance data acquisition and processing. Tobias Gerken provided valuable comments on earlier versions of this manuscript. We also thank the Natural Environment Research Council (NERC) (award NE/D005922, PI M. Williams) for support of Abisko measurements. Any use of trade, firm, or product names is for descriptive purposes only and does not imply endorsement by the U.S. Government.

\section{References}

Abatzoglou, J.T., Rupp, D.E., Mote, P.W., 2014. Seasonal climate variability and change in the Pacific Northwest of the United States. J. Clim. 27, 2125-2142. http://dx.doi. org/10.1175/jcli-d-13-00218.1.

Anthoni, P.M., Freibauer, A., Kolle, O., Schulze, E.-D., 2004. Winter wheat carbon exchange in Thuringia. Ger. Agric. For. Meteorol. 121 (1-2), 55-67.

Arck, M., Scherer, D., 2002. Problems in the determination of sensible heat flux over snow. Geogr. Ann. Ser. Phys. Geogr. 84, 157-169. http://dx.doi.org/10.1111/j.04353676.2002.00170.x.

Aurela, M., Lohila, A., Tuovinen, J.P., Hatakka, J., Riutta, T., Laurila, T., 2009. Carbon dioxide exchange on a northern boreal fen. Boreal Environ. Res. 14, 699-710.

Beaty, C.B., 1975. Sublimation or melting: observations from the white mountains, California and Nevada. U.S.A. J. Glaciol. 14, 275-286. http://dx.doi.org/10.1017/ S0022143000021766.

Bedford, D., Douglass, A., 2008. Changing properties of snowpack in the Great Salt Lake Basin, western United States, from a 26-year SNOTEL record. Prof. Geogr. 60, 374-386.

Boike, J., 2003. Seasonal snow cover on frozen ground: energy balance calculations of a permafrost site near Ny-Ålesund, Spitsbergen. J. Geophys. Res. 108. http://dx.doi. org/10.1029/2001JD000939.

Boon, S., 2009. Snow ablation energy balance in a dead forest stand. Hydrol. Process. 23, 2600-2610. http://dx.doi.org/10.1002/hyp.7246.

Burns, S.P., Molotch, N.P., Williams, M.W., Knowles, J.F., Seok, B., Monson, R.K., Turnipseed, A.A., Blanken, P.D., 2014. Snow temperature changes within a seasonal snowpack and their relationship to turbulent fluxes of sensible and latent heat. J. Hydrometeorol. 15, 117-142.

Campbell, G.S., Norman, J.M., 1998. An Introduction to Environmental Biophysics. Springer New York, New York, NY.

Cline, D.W., 1997. Snow surface energy exchanges and snowmelt at a continental, midlatitude Alpine site. Water Resour. Res. 33, 689-701. http://dx.doi.org/10.1029/ 97WR00026.

Coughlan, J.C., Running, S.W., 1997. Regional ecosystem simulation: a general model for simulating snow accumulation and melt in mountainous terrain. Landscape Ecol. 12, 119-136.
Conway, H., Gades, A., Raymond, C.F., 1996. Albedo of dirty snow during conditions of melt. Water Resour. Res. 32, 1713-1718. http://dx.doi.org/10.1029/96WR00712.

Dettinger, M., Udall, B., Georgakakos, A., 2015. Western water and climate change. Ecol. Appl. 25, 2069-2093. http://dx.doi.org/10.1890/15-0938.1.

Desai, A.R., Wohlfahrt, G., Zeeman, M.J., Katata, G., Eugster, W., Montagnani, L., Mauder, M., Schmid, H.-P., 2016. Montane ecosystem productivity responds more to global circulation patterns than climatic trends. Environ. Res. Lett. 11 (2), 024013. http://dx.doi.org/10.1088/1748-9326/11/2/024013.

Endrizzi, S., Marsh, P., 2010. Observations and modeling of turbulent fluxes during melt at the shrub-tundra transition zone 1: point scale variations. Hydrol. Res. 41, 471. http://dx.doi.org/10.2166/nh.2010.149.

Eugster, W., Zeeman, M.J., 2006. Micrometeorological techniques to measure ecosystemscale greenhouse gas fluxes for model validation and improvement. Int. Congr. Ser. 1293, 66-75.

Fitzpatrick, N., Radić, V., Menounos, B., 2017. Surface energy balance closure and turbulent flux parameterization on a mid-latitude mountain glacier, purcell mountains, Canada. Front. Earth Sci. 5, 67.

Fletcher, B.J., Gornall, J.L., Poyatos, R., Press, M.C., Stoy, P.C., Huntley, B., Baxter, R., Phoenix, G.K., 2012. Photosynthesis and productivity in heterogeneous arctic tundra: consequences for ecosystem function of mixing vegetation types at stand edges. J. Ecol. 100, 441-451. http://dx.doi.org/10.1111/j.1365-2745.2011.01913.x.

Fox, A.M., Huntley, B., Lloyd, C.R., Williams, M., Baxter, R., 2008. Net ecosystem exchange over heterogeneous arctic tundra: scaling between chamber and eddy covariance measurements. Global Biogeochem. Cycles 22, GB2027. http://dx.doi.org/ 10.1029/2007GB003027.

Goff, J., Gratch, S., 1945. Thermodynamic properties of moist air. ASHVE Trans. 51, 125-158.

Goulden, M.L., Daube, B.C., Fan, S.-M., Sutton, D.J., Bazzaz, A., Munger, J.W., Wofsy, S.C., 1997. Physiological responses of a black spruce forest to weather. J. Geophys. Res. Atmos. 102, 28987-28996.

Grundstein, A.J., Leathers, D.J., 1999. A spatial analysis of snow-surface energy exchanges over the northern great plains of the United States in relation to synoptic scale forcing mechanisms. Int. J. Climatol. 19, 489-511.

Harding, R.J., Pomeroy, J.W., 1996. The energy balance of the winter boreal landscape. J. Clim. 9, 2778-2787.

Hawkins, T.W., Ellis, A.W., 2007. A case study of the energy budget of a snowpack in the arid, subtropical climate of the southwestern United States. J. Ariz. Nev. Acad. Sci. $39,1-13$.

Hayashi, M., Hirota, T., Iwata, Y., Takayabu, I., 2005. Snowmelt energy balance and its relation to foehn events in Tokachi. Jpn. J. Meteorol. Soc. Jpn. 83, 783-798.

Hommeltenberg, J., Schmid, H.P., Drösler, M., Werle, P., 2014. Can a bog drained for forestry be a stronger carbon sink than a natural bog forest? Biogeosciences 11 , 3477-3493.

Hood, E., Williams, M., Cline, D., 1999. Sublimation from a seasonal snowpack at a continental, mid-latitude alpine site. Hydrol. Process. 13, 1781-1797.

Hori, M., Aoiki, T., Tanikawa, T., Motoyoshi, H., Hachikubo, A., Sugiura, K., Yasunari, T., Eide, H., Storvold, R., Nakajima, Y., Takahashi, F., 2006. In-situ measured spectral directional emissivity of snow and ice in the 8-14 $\mu \mathrm{m}$ atmospheric window. Remote Sens. Environ. 100, 486-502.

Jocher, G., Ottosson Löfvenius, M., De Simon, G., Hörnlund, T., Linder, S., Lundmark, T., Marshall, J., Nilsson, M.B., Näsholm, T., Tarvainen, L., Öquist, M., Peichl, M., 2017. Apparent winter $\mathrm{CO} 2$ uptake by a boreal forest due to decoupling. Agric. For. Meteorol. 232, 23-34. http://dx.doi.org/10.1016/j.agrformet.2016.08.002.

Jonas, T., Rixen, C., Sturm, M., Stoeckli, V., 2008. How alpine plant growth is linked to snow cover and climate variability. J. Geophys. Res: Biogeosci. 113, G03013. http:// dx.doi.org/10.1029/2007JG000680.

Julitta, T., Cremonese, E., Migliavacca, M., Colombo, R., Galvagno, M., Siniscalco, C., Rossini, M., Fava, F., Cogliati, S., Morra di Cella, U., Menel, A., 2014. Using digital camera images to analyse snowmelt and phenology of a subalpine grassland. Agric. For. Meteorol. 198-199, 116-125. http://dx.doi.org/10.1016/j.agrformet.2014.08. 007.

Kaimal, J.C., Finnigan, J.J., 1994. Atmospheric Boundary Layer Flows: Their Structure and Measurement. Oxford University Press.

Kay, A.L., Crooks, S.M., 2014. An investigation of the effect of transient climate change on snowmelt, flood frequency and timing in northern Britain. Int. J. Climatol. 34, 3368-3381. http://dx.doi.org/10.1002/joc.3913.

Kottek, M., Grieser, J., Beck, C., Rudolf, B., Rubel, F., 2006. World map of the KöppenGeiger climate classification updated. Meteorol. Z. 15, 259-263. http://dx.doi.org/ 10.1127/0941-2948/2006/0130.

Liljedahl, A.K., Hinzman, L.D., Harazono, Y., Zona, D., Tweedie, C.E., Hollister, R.D., Engstrom, R., Oechel, W.C., 2011. Nonlinear controls on evapotranspiration in arctic coastal wetlands. Biogeosciences 8, 3375-3389.

Loescher, H.W., Hanson, C.V., Ocheltree, T.W., 2009. The psychrometric constant is not constant: a novel approach to enhance the accuracy and precision of latent energy fluxes through automated water vapor calibrations. J. Hydrometeorol. 10, 1271-1284.

MacDonald, M.K., Pomeroy, J.W., Essery, R.L.H., 2018. Water and energy fluxes over northern prairies as affected by chinook winds and winter precipitation. Agric. For. Meteorol. http://dx.doi.org/10.1016/j.agrformet.2017.10.025.

Mahrt, L., Vickers, D., 2005. Moisture fluxes over snow with and without protruding vegetation. Q. J. R. Meteorol. Soc. 131, 1251-1270. http://dx.doi.org/10.1256/qj 04.66 .

Marcolla, B., Cescatti, A., Manca, G., Zorer, R., Cavagna, M., Fiora, A., Gianelle, D., Rodeghiero, M., Sottocornola, M., Zampedri, R., 2011. Climatic controls and ecosystem responses drive the inter-annual variability of the net ecosystem exchange of an alpine meadow. Agric. For. Meteorol. 151, 1233-1243. 
Marks, D., Dozier, J., 1992. Climate and energy exchange at the snow surface in the alpine region of the Sierra Nevada: 2. Snow cover energy balance. Water Resour. Res. 28, 3043-3054. http://dx.doi.org/10.1029/92WR01483.

Marks, D., Winstral, A., 2001. Comparison of snow deposition, the snow cover energy balance, and snowmelt at two sites in a semiarid mountain basin. J. Hydrometeorol. 2, 213-227. http://dx.doi.org/10.1175/1525-7541(2001)002\&0213:COSDTS\&2.0. CO; 2 .

Marks, D., Winstral, A., Flerchinger, G., Reba, M., Pomeroy, J., Link, T., Elder, K., 2008. Comparing simulated and measured sensible and latent heat fluxes over snow under a pine canopy to improve an energy balance snowmelt model. J. Hydrometeorol. 9, 1506-1522. http://dx.doi.org/10.1175/2008JHM874.1.

Migliavacca, M., Galvagno, M., Cremonese, E., Rossini, M., Meroni, M., Sonnentag, O., Cogliati, S., Manca, G., Diotri, F., Busetto, L., Cescatti, A., 2011. Using digital repeat photography and eddy covariance data to model grassland phenology and photosynthetic CO2 uptake. Agric. For. Meteorol 151, 1325-1337.

Misson, L., Baldocchi, D.D., Black, T.A., Blanken, P.D., Brunet, Y., Curiel Yuste, J., Dorsey, J.R., Falk, M., Granier, A., Irvine, M.R., Jarosz, N., Lamaud, E., Launiainen, S., Law, B.E., Longdoz, B., Loustau, D., McKay, M., Paw U, K.T., Vesala, T., Vickers, D., Wilson, K.B., Goldstein, A.H., 2007. Partitioning forest carbon fluxes with overstory and understory eddy-covariance measurements: a synthesis based on FLUXNET data. Agric. For. Meteorol. 144, 14-31. http://dx.doi.org/10.1016/j.agrformet.2007.01. 006.

Molotch, N.P., Blanken, P.D., Williams, M.W., Turnipseed, A.A., Monson, R.K., Margulis, S.A., 2007. Estimating sublimation of intercepted and sub-canopy snow using eddy covariance systems. Hydrol. Process. 21, 1567-1575. http://dx.doi.org/10.1002/ hyp.6719.

Mott, R., Egli, L., Grünewald, T., Dawes, N., Manes, C., Bavay, M., Lehning, M., 2011. Micrometeorological processes driving snow ablation in an Alpine catchment. The Cryosphere 5, 1083-1098. http://dx.doi.org/10.5194/tc-5-1083-2011.

Mott, R., Gromke, C., Grunewald, T., Lehning, M., 2013. Relative importance of advective heat transport and boundary layer decoupling in the melt dynamics of a patchy snow cover. Adv. Water Resour. 55, 88-97. http://dx.doi.org/10.1016/j.advwatres.2012. 03.001.

Musselman, K.N., Clark, M.P., Liu, C., Ikeda, K., Rasmussen, R., 2017. Slower snowmelt in a warmer world. Nat. Clim. Change 7, 214-219. http://dx.doi.org/10.1038/ nclimate3225.

Owen, K.E., Tenhunen, J., Reichstein, M., Wang, Q., Falge, E., Geyer, R., Xiao, X., Stoy, P.C., Amman, C., Arain, A., Aubinet, M., Aurela, M., Bernhofer, C., Chojnicki, B., Granier, A., Gruenwald, T., Hadley, J., Heinesch, B., Hollinger, D., Knohl, A., Kutsch, W., Laurila, T., Lohila, A., Meyers, T., Moors, E., Moureaux, C., Verma, S., Vesala, T., Vogel, C.S., 2007. Linking flux network measurements to continental scale simulations: ecosystem carbon dioxide exchange capacity under non-water- stressed conditions. Global Change Biol. 13, 734-760.

Pastorello, G.Z., Papale, D., Chu, H., Trotta, C., Agarwal, D.A., Canfora, E., Baldocchi, D.D., Torn, M.S., 2017. A new data set to keep a sharper eye on land-air exchanges. Eos Trans. AGU 98. http://dx.doi.org/10.1029/2017EO071597.

Pederson, G.T., Betancourt, J.L., McCabe, G.J., 2013. Regional patterns and proximal causes of the recent snowpack decline in the rocky mountains, U.S.: proximal causes of snowpack declines. Geophys. Res. Lett. 40, 1811-1816. http://dx.doi.org/10. 1002/grl.50424.

Pederson, G.T., Gray, S.T., Woodhouse, C.A., Betancourt, J.L., Fagre, D.B., Littell, J.S. Watson, E., Luckman, B.H., Graumlich, L.J., 2011. The unusual nature of recent snowpack declines in the North American Cordillera. Science 333 (6040), 332-335. http://dx.doi.org/10.1126/science.1201570.

Pohl, S., Marsh, P., Liston, G.E., 2006. Spatial-temporal variability in turbulent fluxes during spring snowmelt. Arct. Antarct. Alp. Res. 38, 136-146.

Reba, M.L., Link, T.E., Marks, D., Pomeroy, J., 2009. An assessment of corrections for Eddy covariance measured turbulent fluxes over snow in mountain environments: Eddy covariance over snow in mountain environments. Water Resour. Res. 45. http://dx.doi.org/10.1029/2008WR007045.

Richardson, A.D., Braswell, B.H., Hollinger, D.Y., Jenkins, J.P., Ollinger, S.V., 2009.
Near-surface remote sensing of spatial and temporal variation in canopy phenology. Ecol. Appl. 19, 1417-1428.

Serreze, M.C., Clark, M.P., Armstrong, R.L., McGinnis, D.A., Pulwarty, R.S., 1999.

Characteristics of the western United States snowpack from snowpack telemetry (SNOTEL) data. Water Resour. Res. 35, 2145-2160.

Slaughter, A.E., McCabe, D., Munter, H., Staron, P.J., Adams, E.E., Catherine, D., Henninger, I., Cooperstein, M., Leonard, T., 2009. An investigation of radiation-recrystallization coupling laboratory and field studies. Cold Reg. Sci. Technol. 59, 126-132. http://dx.doi.org/10.1016/j.coldregions.2009.07.002.

Spadavecchia, L., Williams, M., Bell, R., Stoy, P.C., Huntley, B., van Wijk, M.T., 2008. Topographic controls on the leaf area index and plant functional type of a tundra ecosystem. J. Ecol. 96, 1238-1251. http://dx.doi.org/10.1111/j.1365-2745.2008. 01424.x.

Staebler, R.M., Fitzjarrald, D.R., 2004. Observing subcanopy CO2 advection. Agric. For. Meteorol. 122, 139-156. http://dx.doi.org/10.1016/j.agrformet.2003.09.011.

Stoy, P.C., Street, L.E., Johnson, A.V., Prieto-Blanco, A., Ewing, S.A., 2012. Temperature, heat flux, and reflectance of common subarctic mosses and lichens under field conditions: might changes to community composition impact climate-relevant surface fluxes? Arct. Antarct. Alp. Res. 44, 500-508. http://dx.doi.org/10.1657/1938-424644.4.500.

Stoy, P.C., Williams, M., Evans, J.G., Prieto-Blanco, A., Disney, M., Hill, T.C., Ward, H.C., Wade, T.J., Street, L.E., 2013. Upscaling tundra CO2 exchange from chamber to eddy covariance tower. Arct. Antarct. Alp. Res. 45, 275-284. http://dx.doi.org/10.1657/ 1938-4246-45.2.275.

Stoy, P.C., Quaife, T., 2015. Probabilistic downscaling of remote sensing data with applications for multi-scale biogeochemical flux modeling. PloS One 10, p.e0128935.

Street, L.E., Stoy, P.C., Sommerkorn, M., Fletcher, B.J., Sloan, V.L., Hill, T.C., Williams, M., 2012. Seasonal bryophyte productivity in the sub-arctic: a comparison with vascular plants: seasonal bryophyte productivity in the sub-arctic. Funct. Ecol. 26 365-378. http://dx.doi.org/10.1111/j.1365-2435.2011.01954.x.

Thomas, C.K., Martin, J.G., Law, B.E., Davis, K., 2013. Toward biologically meaningful net carbon exchange estimates for tall, dense canopies: multi-level eddy covariance observations and canopy coupling regimes in a mature Douglas-fir forest in Oregon. Agric. For. Meteorol. 173, 14-27. http://dx.doi.org/10.1016/j.agrformet.2013.01. 001.

Troin, M., Poulin, A., Baraer, M., Brissette, F., 2016. Comparing snow models under current and future climates: uncertainties and implications for hydrological impact studies. J. Hydrol. 540, 588-602. http://dx.doi.org/10.1016/j.jhydrol.2016.06.055.

Verma, S.B., Dobermann, A., Cassman, K.G., 2005. Annual carbon dioxide exchange in irrigated and rainfed maize-based agroecosystems. Agric. For. Meteorol. 131, 77-96.

Warren, S.G., 1984. Impurities in snow: effects on albedo and snowmelt. Ann. Glaciol. 5, 177-179.

Welch, C.M., Stoy, P.C., Rains, F.A., Johnson, A.V., McGlynn, B.L., 2016. The impacts of mountain pine beetle disturbance on the energy balance of snow during the melt period: snowmelt response to mountain pine beetle disturbance. Hydrol. Process. 30 (4), 588-602. http://dx.doi.org/10.1002/hyp.10638.

Wever, N., Vera Valero, C., Fierz, C., 2016. Assessing wet snow avalanche activity using detailed physics based snowpack simulations. Geophys. Res. Lett. 43, 5732-5740. http://dx.doi.org/10.1002/2016g1068428.

Wohlfahrt, G., Hammerle, A., Haslwanter, A., Bahn, M., Tappeiner, U., Cernusca, A., 2008. Seasonal and inter-annual variability of the net ecosystem $\mathrm{CO}_{2}$ exchange of a temperate mountain grassland: effects of weather and management. J. Geophys. Res. 113 (D8), D08110.

Wiscombe, W.J., Warren, S.G., 1980. A model for the spectral albedo of snow. I: pure snow. J. Atmos. Sci. 37, 2712-2733.

Zeeman, M.J., Mauder, M., Steinbrecher, R., Heidbach, K., Eckart, E., Schmid, H.P., 2017. Reduced snow cover affects productivity of upland temperate grasslands. Agric. For. Meteorol. 232, 514-526. http://dx.doi.org/10.1016/j.agrformet.2016.09.002.

Zhu, G., He, Y., Pu, T., Wang, X., Jia, W., Li, Z., Xin, H., 2012. Spatial distribution and temporal trends in potential evapotranspiration over Hengduan Mountains region from 1960 to 2009. J. Geogr. Sci. 22, 71-85. 